\title{
Effects of supplemental chromium and heat exposure on glucose metabolism and insulin action in sheep
}

\author{
H. SANO*, S. KONNO AND A. SHIGA \\ Faculty of Agriculture, Iwate University, Morioka 020-8550, Japan \\ (Revised MS received 26 November 1999)
}

\begin{abstract}
SUMMARY
An isotope dilution method using $\left[\mathrm{U}-{ }^{13} \mathrm{C}\right]$ glucose and a glucose clamp approach were applied to determine the effects of supplemental chromium $(\mathrm{Cr})$ and heat exposure on blood glucose metabolism and tissue responsiveness and sensitivity to insulin in sheep. The sheep consumed diets with either 0 or $1 \mathrm{mg}$ of $\mathrm{Cr} / \mathrm{kg}$ (Control and $+\mathrm{Cr}$ diet, respectively) from high-Cr-yeast, and were exposed from a thermoneutral environment $\left(20^{\circ} \mathrm{C}\right)$ to a hot environment $\left(30^{\circ} \mathrm{C}\right)$ for 5 days. Blood glucose turnover rate did not differ between the diets, and was lower $(P<0.05)$ during heat exposure than in the thermoneutral environment. The maximal glucose infusion rate (tissue responsiveness to insulin) tended to be lower $(P=0.06)$ for the $+\mathrm{Cr}$ diet than for the Control diet, but did not change with heat exposure. The plasma insulin concentration at half maximal glucose infusion rate (tissue sensitivity to insulin) did not differ between the diets, and was greater $(P<0.05)$ during heat exposure than in the thermoneutral environment. No significant diet $x$ environment interactions were observed. There was no significant evidence that $\mathrm{Cr}$ supplementation moderated heat stress in sheep from the measures of blood glucose metabolism and insulin action.
\end{abstract}

\section{INTRODUCTION}

Chromium (Cr) is a trace mineral that is essential for normal glucose and lipid metabolism, and is considered to be a component of the bioactive glucose tolerance factor (Mertz 1993). Moonsie-Shageer \& Mowat (1993) reported that a $27 \%$ increase in average daily gain was observed at day 30 for calves fed $0 \cdot 2$ and $1 \mathrm{mg} / \mathrm{kg}$ of supplemental $\mathrm{Cr}$ from a high-Cryeast to a maize silage-based diet that contained $\mathrm{Cr}$ at a level of $0.16 \mathrm{mg} / \mathrm{kg}$. Supplemental $\mathrm{Cr}(4.25$ to $7.75 \mathrm{mg}$ of $\mathrm{Cr}$ as amino acid-chelated $\mathrm{Cr}$ ) increased milk production in first parity cows fed a basal diet that contained $\mathrm{Cr}$ at levels of 0.79 to $1.60 \mathrm{mg} / \mathrm{kg}$ (Yang et al. 1996). Therefore, dietary Cr supplementation may influence intermediary metabolism and endocrine status, but the data on blood glucose metabolism are highly limited in ruminants (Sano et al. 1997). The data on tissue responsiveness and sensitivity to insulin as assessed by a hyperinsulinaemic euglycaemic clamp approach are also limited in ruminants fed diets supplemented with $\mathrm{Cr}$ (Borgs et al. 1997; Sano et al. 1999). Heat exposure is one of the stresses which produces a variety of negative effects on productivity of livestock through reduced feed intake and elevated body temperature, and it may

\footnotetext{
* To whom all correspondence should be addressed.
}

also modify Cr status (Johnson \& Vanjonack 1975; Mowat 1997). This experiment was designed to measure blood glucose turnover rate, as measured by an isotope dilution method using a stable isotope (Sano et al. 1996), and tissue responsiveness and sensitivity to insulin measured using the glucose clamp approach (De Fronzo et al. 1979) in sheep fed diets supplemented either with or without $\mathrm{Cr}$, and exposed from a thermoneutral environment to a hot environment.

\section{MATERIALS AND METHODS Animals, diets and environments}

Eight crossbred (Corriedale $\times$ Suffolk) shorn sheep, aged 2 to 4 years and weighing $43 \pm 3 \mathrm{~kg}$ were used. More than 3 months before the experiment, the sheep were surgically prepared under anaesthesia with a skin loop enclosing the left carotid artery. Animals were housed in individual metabolic cages in a controlled environment chamber at an air temperature of $20 \pm 1{ }^{\circ} \mathrm{C}$. The animals were fed at $2 \%$ of liveweight (LW) of a basal diet (lucerne hay cubes $(0.88$ dry matter): ground maize $(0.85$ dry matter $)=1: 1)$ once daily at $17.00 \mathrm{~h}$. Water was available ad libitum. The basal diet was estimated to contain 9.6 MJ metabolizable energy $/ \mathrm{kg}$ (NRC 1985). Chromium levels in the 
basal diet were 1.0 and $0.4 \mathrm{mg} / \mathrm{kg}$ for lucerne hay cubes and ground maize, respectively. The dietary treatments consisted of supplementing the basal diet with either 0 or $1 \mathrm{mg}$ of $\mathrm{Cr} / \mathrm{kg}$ of diet (Control diet and $+\mathrm{Cr}$ diet, respectively) from high-Cr-yeast ( $1 \mathrm{~g}$ of $\mathrm{Cr} / \mathrm{kg}$, Chromium Yeast, Alltech Inc., USA). Therefore, the Control and $+\mathrm{Cr}$ diets contained $0 \cdot 7$ and $1.7 \mathrm{mg}$ of $\mathrm{Cr} / \mathrm{kg}$, respectively. Sheep were assigned to the two dietary treatments, and groups of four sheep were fed either the Control or $+\mathrm{Cr}$ diet for 5 weeks as a preliminary period. A catheter for infusion was inserted into a jugular vein on the day before the determination of blood glucose metabolism in the thermoneutral environment and was maintained until the end of the experiment. A catheter for blood sampling was inserted into the skin loop of the carotid artery on the morning of each determination of blood glucose metabolism and insulin action. Catheters were filled with a sterile solution of $3.8 \%$ (wt/vol) trisodium citrate. After determinations in the thermoneutral environment were completed, sheep were exposed to a hot environment $\left(30 \pm 2{ }^{\circ} \mathrm{C}\right)$ for 5 days, and determinations were repeated as in the thermoneutral environment. Blood samples for determinations of glucose metabolism and insulin action were obtained from the sampling catheters without noticeable stress to the sheep apart from the direct responses to heat exposure. The surgery and blood sampling were carried out according to the guidelines established by the Animal Care Committee of Iwate University.

\section{Experimental procedures}

Heart rate was measured and blood sample $(10 \mathrm{ml})$ was withdrawn from the arterial loop by venipuncture at $09.00 \mathrm{~h}$ for 5 days in both environments. Blood samples fc. metabolite and hormone determinations were transferred to centrifuge tubes containing heparin sodium and were chilled until centrifugation. Feed was removed at $09.00 \mathrm{~h}$ and not offered again until $17.00 \mathrm{~h}$, except on the day of the glucose clamp approach when the diet was not offered during the blood sampling period.

The isotope dilution method for determination of blood glucose turnover rate was carried out in the thermoneutral environment and on the second day of heat exposure. At $11.00 \mathrm{~h}, 10 \mathrm{mg}$ of $\left[\mathrm{U}^{13} \mathrm{C}\right]$ glucose (D-glucose- ${ }^{13} \mathrm{C}_{6}, 99$ atom \% excess ${ }^{13} \mathrm{C}$; Isotec Inc., A Matheson, USA Co., USA) dissolved in $10 \mathrm{ml}$ of saline solution $(0.9 \%$ sodium chloride; wt/vol) was injected into the jugular catheter as a priming dose. $\left[\mathrm{U}-{ }^{13} \mathrm{C}\right]$ Glucose $(300 \mathrm{mg} / 10 \cdot 9 \%$ sodium chloride) was then continuously infused by a multichannel peristaltic pump (AC-2120, Atto Co. Ltd., Japan) at a rate of $3 \mu \mathrm{g} / \mathrm{kg} \mathrm{LW} / \mathrm{min}$ through the same catheter for $4 \mathrm{~h}$. Blood samples $(5 \mathrm{ml})$ were taken from the catheter for blood sampling immediately before and at $120,150,180,210$ and $240 \mathrm{~min}$ after the initiation of $\left[\mathrm{U}^{-13} \mathrm{C}\right]$ glucose infusion. Samples were transferred into centrifuge tubes containing heparin sodium and were chilled until centrifugation.

The hyperinsulinaemic euglycaemic clamp approach was conducted to determine tissue responsiveness and sensitivity to insulin 3 days after carrying out the isotope dilution method in both environments. Insulin (400 U/1, bovine insulin, Sigma Company, USA), dissolved in $0.9 \%$ sodium chloride, was given by continuous infusion over four sequential 2-h periods at rates of $0.64,1.6,4.0$ and $10 \mathrm{mU} / \mathrm{kg}$ $\mathrm{LW} / \mathrm{min}$ via the infusion catheter using the multichannel peristaltic pump (Janes et al. 1985; Sano et al. 1999). Blood samples $(1 \mathrm{ml})$ were taken from the sampling catheter at 5-min intervals, and blood glucose concentrations were determined within $1 \mathrm{~min}$ after each blood sampling to decide glucose infusion rates with an automated glucose analyser (GLU-1, Erma Optical Works, Japan). Immediately after determination of blood glucose concentration, a $20 \%$ $(\mathrm{wt} / \mathrm{vol})$ glucose solution was infused at variable rates through the same infusion catheter using another peristaltic pump to maintain preinfusion concentrations of blood glucose. Blood samples $(3 \mathrm{ml})$ for insulin assay taken at 30-min intervals were transferred to centrifuge tubes that contained anticoagulant and were stored in ice-water until centrifugation. The amount of glucose infused was recorded every $10 \mathrm{~min}$ throughout the 8-h period of insulin infusion. After finishing the insulin infusion, glucose infusion was continued while blood glucose concentrations were monitored for a minimum of $1 \mathrm{~h}$ to prevent hypoglycaemia.

\section{Chemical analysis}

Blood samples were centrifuged at $4500 \mathrm{~g}$ for $10 \mathrm{~min}$ at $4{ }^{\circ} \mathrm{C}$ (RS-18IV, Tomy, Japan), and the plasma was stored at $-25^{\circ} \mathrm{C}$ until further analyses. Concentrations of plasma glucose were determined with the automated glucose analyser. Derivatization of plasma glucose was performed by the procedure of Tserng \& Kalhan (1983) with slight modifications as described previously (Sano et al. 1996). The isotopic abundance of the glucose derivative was determined with a gas chromatography-combustion-isotope ratio mass spectrometry (DELTA ${ }^{\text {plus }}$, Finnigan, England). Plasma insulin and cortisol concentrations were measured with RIA kits (IRI 'Eiken' and Cortisol 'Eiken', Eiken Chemical Co., Japan) based on a double-antibody method. Intraassay coefficients of variation were 5.7 and $6.8 \%$, respectively. Concentrations of plasma nonesterified fatty acid (NEFA) were determined with a kit (NEFA C test, Wako Pure Chemical Industries, Ltd., Japan). Concentrations of plasma lactate were determined by the method described by Taylor (1996). Chromium contents in diets were determined by an atomic absorption spectrophotometer (HGA 600, Perkin-Elmer 
Corporation, USA). All analyses were performed in a single assay.

\section{Calculations}

Mean values with standard errors are given. For the isotope dilution method, the turnover rate of blood glucose was calculated using the equation described by Tserng \& Kalhan (1983). For the glucose clamp approach, mean values for glucose infusion rates (GIR) and plasma insulin concentrations (MPI) during the second half of each 2-h insulin infusion were calculated (Sano et al. 1999). The GIR and MPI were used for calculating the maximal GIR $\left(\mathrm{GIR}_{\max }\right)$ and the insulin concentration at half-maximal GIR $\left(E D_{50}\right)$. These were obtained from a regression equation of a logistic curve plotting the logarithm of MPI v. GIR. The $\mathrm{GIR}_{\max }$ and $\mathrm{ED}_{50}$ were used to assess tissue responsiveness and sensitivity to insulin, respectively (Kahn 1978).

The data were analysed with the General Linear Model procedure of the Statistical Analysis System (1985). A split-plot design was used to test for the effects of diet, environment and their interaction. The main plot was diet, and the subplot was environment and the interaction. For the glucose clamp approach, a repeated measures approach was used to analyse the interaction between insulin infusion rates among treatments. A one-way analysis of variance and Duncan's test were used to test differences between insulin infusion rates. For daily profiles, Student's $t$ tests were used to compare the least squares means for the thermoneutral environment and during heat exposure. Results were considered significant at the $P<0.05$ level.

\section{RESULTS}

Feed intake was for all groups $20 \mathrm{~g} / \mathrm{kg} \mathrm{LW} /$ day. Weight change was $0 \pm 0.1 \mathrm{~kg} /$ day. Mean heart rate range was 65 to $72 / \mathrm{min}$ with no significant differences between groups. Concentrations of plasma glucose and lactate remained unchanged during heat exposure in both dietary treatments (Fig. 1). In the thermoneutral environment, plasma NEFA concentrations were lower $(P<0.01)$ for the $+\mathrm{Cr}$ diet than for the Control diet. The concentrations for the Control diet decreased $(P<0.01)$ during heat exposure, whereas the decreases were not significant for the $+\mathrm{Cr}$ diet. Plasma insulin concentrations increased $(P<0.01)$ during heat exposure in both dietary treatments. Plasma cortisol concentrations were numerically lower for the $+\mathrm{Cr}$ diet than for the Control diet in the thermoneutral environment. The concentrations for the Control diet decreased $(P<0.01)$ during heat exposure, whereas those for the $+\mathrm{Cr}$ diet remained unchanged.

Plasma glucose concentrations did not change during the period of the isotope dilution procedure

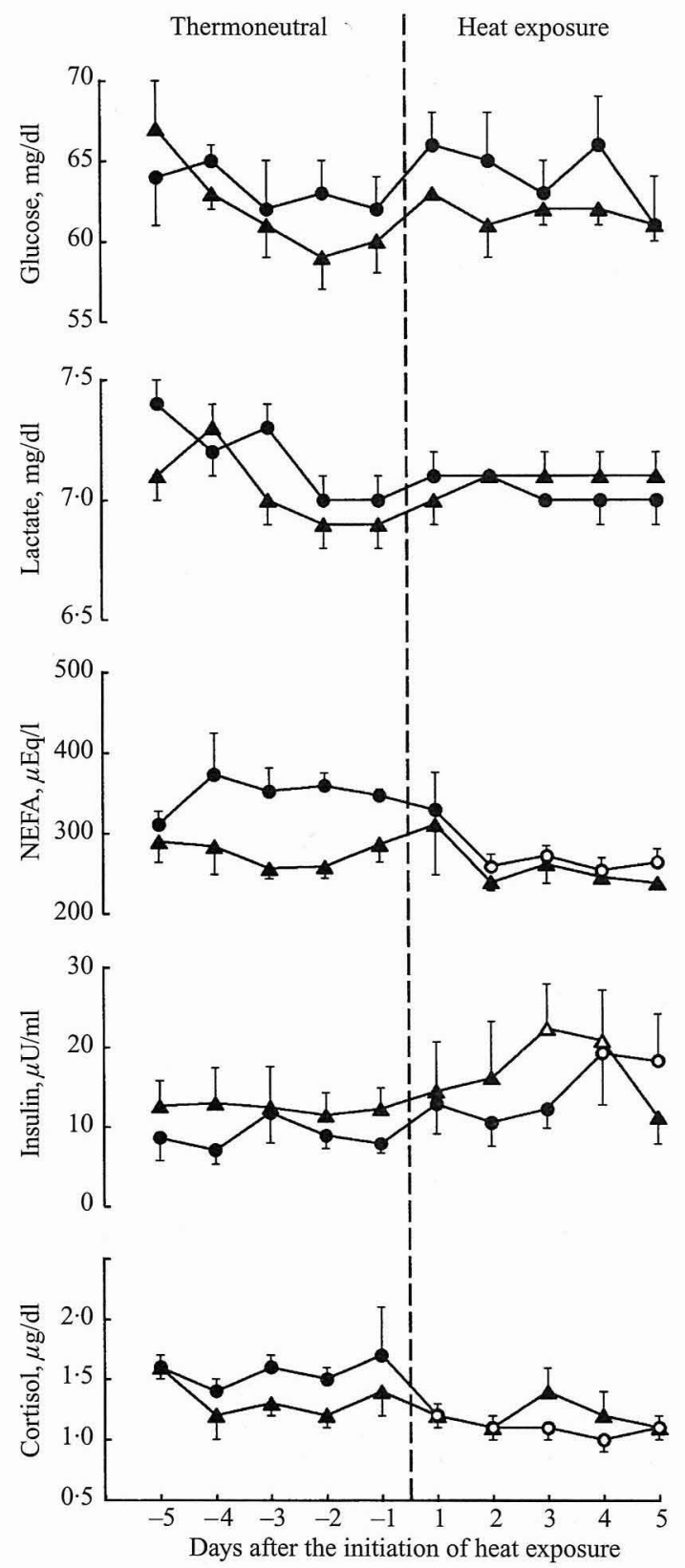

Fig. 1. Daily concentrations of plasma glucose, lactate, NEFA, insulin and cortisol in a thermoneutral environment $\left(20^{\circ} \mathrm{C}\right)$ and over 5 days following exposure to a hot environment $\left(30^{\circ} \mathrm{C}\right)$ in sheep fed diets without (circle: $n=4$ ) and with (triangle: $n=4) 1 \mathrm{mg}$ of supplemental $\mathrm{Cr} / \mathrm{kg}$ of diet, respectively. Open symbols indicate significant differences $(P<0.05)$ from the thermoneutral means.

(data not shown). Infusion rates and plasma glucose enrichments of [U- $\left.{ }^{13} \mathrm{C}\right]$ glucose were virtually constant during the latter half of the $\left[\mathrm{U}-{ }^{13} \mathrm{C}\right]$ glucose infusion. 
Table 1. Effects of $\mathrm{Cr}$ supplementation and heat exposure on blood glucose turnover rate in sheep

\begin{tabular}{|c|c|c|c|c|c|c|c|c|}
\hline & \multicolumn{2}{|l|}{ Control* } & \multicolumn{2}{|l|}{$+\mathrm{Cr}^{*}$} & \multirow[b]{2}{*}{ S.E. } & \multicolumn{3}{|c|}{$P$ values } \\
\hline & Thermoneutral $\dagger$ & Heat $\dagger$ & Thermoneutral & Heat & & Diet & Environment & Interaction \\
\hline No. of sheep & 4 & 4 & 4 & 3 & & & & \\
\hline $\begin{array}{l}\text { Glucose turnover rate, } \\
\mathrm{mg} / \mathrm{kg} \mathrm{LW} / \mathrm{min}\end{array}$ & $2 \cdot 3$ & $1 \cdot 9$ & $2 \cdot 0$ & $1 \cdot 8$ & $0 \cdot 1$ & $0 \cdot 41$ & 0.03 & 0.68 \\
\hline
\end{tabular}

* Control $=$ the basal diet alone; $+\mathrm{Cr}=$ the basal diet with $1 \mathrm{mg}$ of $\mathrm{Cr} / \mathrm{kg}$.

$\dagger$ Thermoneutral $=20 \pm 1{ }^{\circ} \mathrm{C}$; Heat $=30 \pm 2{ }^{\circ} \mathrm{C}$.

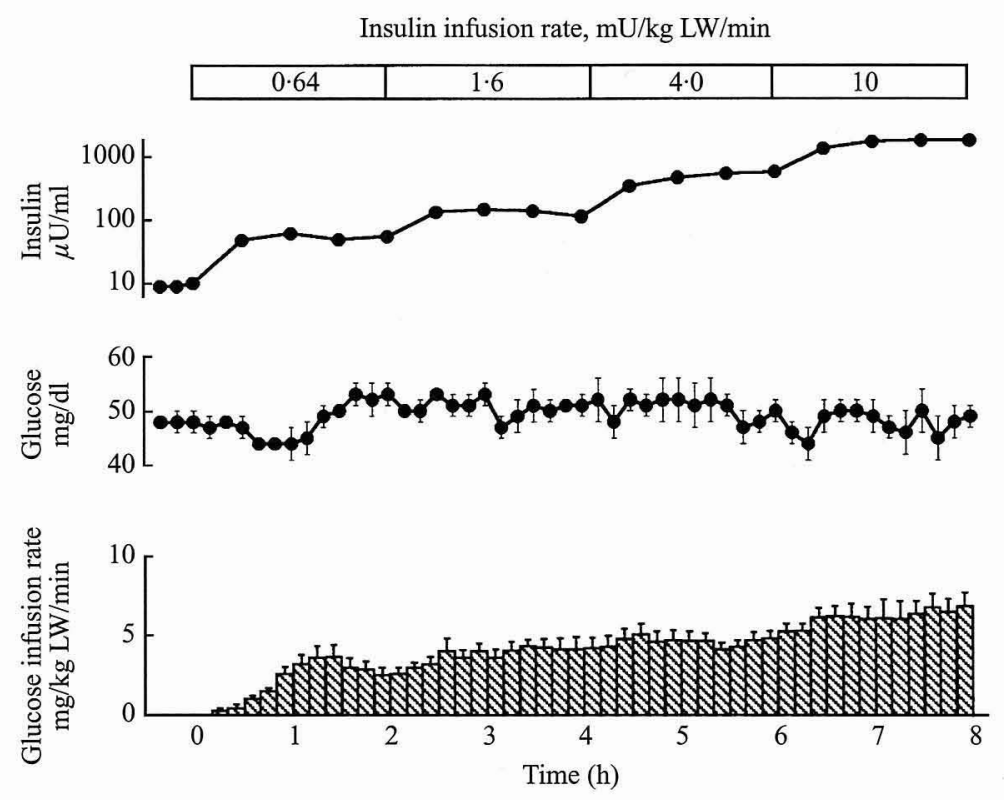

Fig. 2. Plasma insulin and blood glucose concentrations, and glucose infusion rates during the hyperinsulinaemic euglycaemic clamp approach in sheep $(n=4)$ fed the Control diet in the thermoneutral environment $\left(20^{\circ} \mathrm{C}\right)$.

Blood glucose turnover rate did not differ between the Control and $+\mathrm{Cr}$ diets in either environments (Table 1). The rate was lower $(P<0.05)$ during heat exposure than in the thermoneutral environment regardless of the dietary treatment.

The time course of changes in concentrations of plasma insulin and blood glucose and glucose infusion rates during the hyperinsulinaemic euglycaemic clamp approach for the Control diet in the thermoneutral environment is shown in Fig. 2. Plasma insulin concentrations increased $(P<0.001)$ as insulin infusion rate increased, and were virtually constant during the latter half of each 2-h insulin infusion period. The concentrations did not differ between the diets or between environments (Table 2). The concentrations of blood glucose were maintained at close to preinfusion levels during the 8-h period of insulin and glucose infusion for all treatments. Glucose infusion rates increased $(P<0.001)$ with increasing insulin infusion rates. The GIR did not differ between the dietary treatments, and was lower $(P<0.001)$ during heat exposure than in the thermoneutral environment. The diet $\times$ environment interaction for the GIR was significant $(P<0.05)$. The $\mathrm{GIR}_{\max }$ tended to be lower $(P=0.06)$ for the $+\mathrm{Cr}$ diet than for the Control diet, but did not differ between the environments. The $\mathrm{ED}_{50}$ did not differ between the dietary treatments, but was greater $(P<0.05)$ during heat exposure than in the thermoneutral environment. No significant interaction was observed for the GIR $\mathrm{max}_{\text {max }}$ or the $\mathrm{ED}_{50}$.

\section{DISCUSSION}

In the present experiment, a high-Cr-yeast was used as a source of supplemental $\mathrm{Cr}$ because organic $\mathrm{Cr}$ was more biologically active than inorganic $\mathrm{Cr}$ 
Effects of chromium supplementation on glucose metabolism

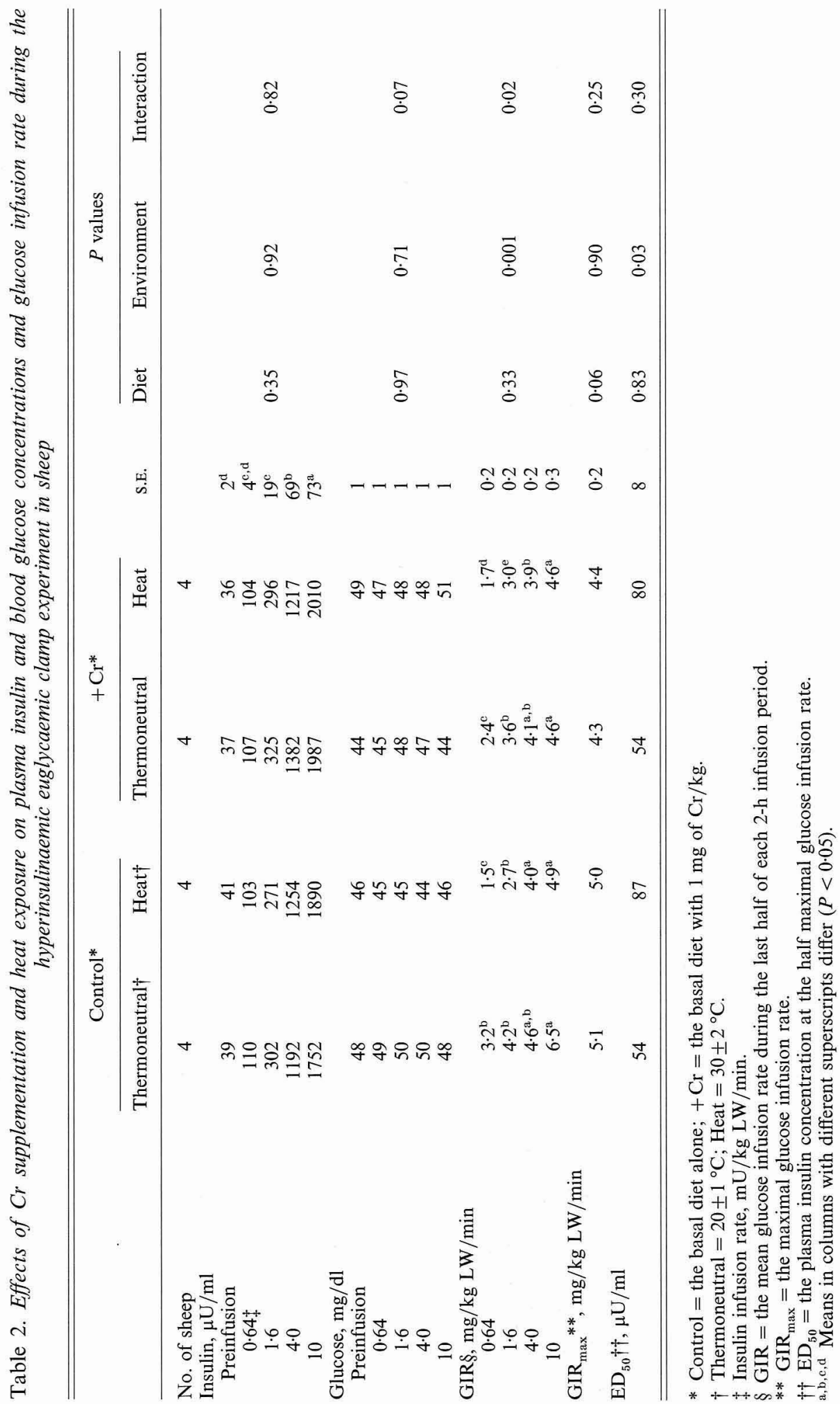


(Mowat 1997). In the thermoneutral environment, plasma NEFA concentrations were reduced $(P<$ 0.01 ) and plasma cortisol concentrations were numerically reduced by $\mathrm{Cr}$ supplementation, as observed in calves (Chang \& Mowat 1992; Moonsie-Shageer \& Mowat 1993; Mowat et al. 1993) and pigs (Amoikon et al. 1995). However, Cr supplementation had limited effects on blood glucose turnover rate as measured by the isotope dilution method. The unchanged rates of blood glucose turnover accorded with the data observed in sheep fed a high grain diet with a different source of $\mathrm{Cr}$ supplementation ( $0.5 \mathrm{mg}$ of $\mathrm{Cr} / \mathrm{kg}$ diet as amino acid-chelated Cr; Sano et al. 1997). For the glucose clamp approach, the GIR $_{\max }$ tended to be lower $(P=0.06)$ for the $+\mathrm{Cr}$ diet than for the Control diet, but the $\mathrm{ED}_{50}$ did not differ. These results suggest that $\mathrm{Cr}$ supplementation had little influence on insulin-independent glucose utilization or insulindependent glucose utilization at the level of the insulin receptor site, whereas it may possibly have reduced insulin-dependent glucose utilization at postreceptor steps. Borgs et al. (1997) applied the full-dose response euglycaemic clamp approach to dairy cattle, and found $\mathrm{Cr}$ supplementation as high-Cr-yeast had little effect on tissue responsiveness to insulin. Our previous results showed that in sheep $\mathrm{Cr}$ supplementation $(0.5 \mathrm{mg}$ of $\mathrm{Cr} / \mathrm{kg}$ diet as high-Cr-yeast) had little influence on tissue responsiveness and sensitivity to insulin measured by the same methodology as in the present experiment (Sano et al. 1999). On the other hand, supplemental $\mathrm{Cr}$ as $\mathrm{Cr}$ tripicolinate was reported to increase insulin sensitivity as measured by an intravenous glucose tolerance test and an intravenous insulin challenge test in calves (Bunting et al. 1994) and in pigs (Amoikon et al. 1995). The results obtained by a full dose-response experiment using the hyperinsulinaemic euglycaemic clamp will not necessarily lead to the same results as when using a single dose of insulin with either the hyperinsulinaemic euglycaemic clamp approach or an intravenous insulin challenge test (Kahn 1978). Therefore, these inconsistencies may partly be attributed to the techniques used for assessing insulin action, in addition to the level or source of supplemental Cr.

The benefits of supplemental $\mathrm{Cr}$ to improve the productivity of ruminants are related to stress, because mobilized $\mathrm{Cr}$ from body reserves is excreted irreversibly into the urine in stressed animals (Chang \& Mowat 1992). Heat stress is one of the stresses that interfere with animal production and theoretically increases the excretion and requirement of $\mathrm{Cr}$ (Johnson \& Vanjonack 1975; Mowat 1997). For the Control diet, plasma NEFA and cortisol concentrations decreased $(P<0.01)$ during heat exposure, whereas no significant change was observed for the $+\mathrm{Cr}$ diet, due to the lower concentrations in the thermoneutral environment. Blood glucose turnover rate decreased during heat exposure in both diets. Sano et al. (1983) observed similar results in sheep exposed to $30^{\circ} \mathrm{C}$ for 10 days and suggested that substrate supply was decreased combined with a decreased hepatic capacity for gluconeogenesis. A lower GIR $(P<0.001)$ and greater $\mathrm{ED}_{50}(P<0.05)$ were observed during heat exposure compared with the thermoneutral environment, whereas the GIR max $_{\max }$ remained unchanged. These imply that heat exposure reduces insulin action through reduced tissue sensitivity to insulin without changing tissue responsiveness to insulin. Achmadi et al. (1993) reported that in sheep exposed to heat $\left(30^{\circ} \mathrm{C}\right)$ for 11 days similar results were observed as determined by a single insulin infusion rate using the hyperinsulinaemic euglycaemic clamp approach. Heat stress may reduce blood glucose turnover rate and glucose uptake by the insulin-dependent tissues, but not intracellular glucose utilization.

No significant interaction between diet and environment was observed in the parameters of blood glucose metabolism and insulin action, except for GIR. Although source and amount of supplemental $\mathrm{Cr}$ influence animal performance and endocrine responses (Moonsie-Shageer \& Mowat 1993; Kegley \& Spears 1995), results were comparable to the present experiment. Therefore, $\mathrm{Cr}$ supplementation may have little effect on parameters of blood glucose metabolism and insulin action in response to heat stress.

In conclusion, $\mathrm{Cr}$ supplementation has little influence on glucose metabolism and insulin action in sheep. Blood glucose metabolism decreases during heat exposure, being partly related to decreased tissue insulin sensitivity together with reduced glucose availability. Moreover, there was no evidence that $\mathrm{Cr}$ supplementation moderates the effects of heat stress on blood glucose metabolism and insulin action.

The authors gratefully acknowledge Dr T. E. C. Weekes, University of Newcastle-upon-Tyne, for his kind comments on the manuscript, and Bayer Ltd., Japan, for the generous donation of high-Cr-yeast.

\section{REFERENCES}

Achmadi, J., Yanagisawa, T., Sano, H. \& Terashima, Y. (1993). Pancreatic insulin secretory response and insulin action in heat-exposed sheep given a concentrate or roughage diet. Domestic Animal Endocrinology 10, 279-287.

Amoikon, E. K., Fernandez, J. M., Southern, L. L.,
ThOmpson, JR, D. L., WARD, T. L. \& OlcotT, B. M. (1995). Effect of chromium tripicolinate on growth, glucose tolerance, insulin sensitivity, plasma metabolites, and growth hormone in pigs. Journal of Animal Science 73, 1123-1130.

Borgs, P., Sefton, A. E. \& Mallard, B. A. (1997). Effect of 
incremental doses of chromium (III) on postpartum insulin resistance in dairy cattle. Journal of Dairy Science $\mathbf{8 0}$ (Suppl.), 186.

Bunting, L. D., Fernandez, J. M., Thompson, JR, D. L. \& SOUTHERN, L. L. (1994). Influence of chromium picolinate on glucose usage and metabolic criteria in growing Holstein calves. Journal of Animal Science 72, 1591-1599.

Chang, X. \& Mowat, D. N. (1992). Supplemental chromium for stressed and growing feeder calves. Journal of Animal Science 70, 559-565.

De Fronzo, R. A., Tobin, J. D. \& Andres, R. (1979). Glucose clamp technique: a method for quantifying insulin secretion and resistance. American Journal of Physiology 237, E214-E223.

Janes, A. N., Weekes, T. E. C. \& Armstrong, D. G. (1985). Insulin action and glucose metabolism in sheep fed on dried-grass or ground, maize-based diets. British Journal of Nutrition 54, 459-471.

Johnson, H. D. \& VANJONACK, W. J. (1975). Effects of environmental and other stressors on blood hormone patterns in lactating animals. Journal of Dairy Science 59, 1603-1617.

KAHN, C. R. (1978). Insulin resistance, insulin insensitivity, and insulin unresponsiveness: a necessary distinction. Metabolism 27, 1893-1902.

KeGley, E. B. \& Spears, J. W. (1995). Immune response, glucose metabolism, and performance of stressed feeder calves fed inorganic or organic chromium. Journal of Animal Science 73, 2721-2726.

Mertz, W. (1993). Chromium in human nutrition: a review. Journal of Nutrition 123, 626-633.

Moonsie-ShageER, S. \& Mowat, D. N. (1993). Effect of level of supplemental chromium on performance, serum constituents, and immune status of stressed feeder calves. Journal of Animal Science 71, 232-238.
Mowat, D. N., Chang, X. \& YANG, W. Z. (1993). Chelated chromium for stressed feeder calves. Canadian Journal of Animal Science 73, 49-55.

Mowat, D. N. (1997). Organic Chromium in Animal Nutrition. Guelph: Chromium Books.

NRC (1985). Nutrient Requirements of Sheep. 6th Rev Edn. Washington, DC: National Academy Press.

Sano, H., Takahashi, K., Аmbo, K. \& Tsuda, T. (1983). Turnover and oxidation rates of blood glucose and heat production in sheep exposed to heat. Journal of Dairy Science 66, 856-861.

Sano, H., Fujta, T., Murakami, M. \& Shiga, A. (1996). Stimulative effect of epinephrine on glucose production and utilization rates in sheep using a stable isotope. Domestic Animal Endocrinology 13, 445-451.

Sano, H., Mowat, D. N., Ball, R. O. \& Trout, D. R. (1997). Effect of supplemental chromium on whole-body kinetics of glucose, lactate, and propionate in rams fed a high grain diet. Comparative Biochemistry and Physiology 118B, 117-121.

Sano, H., Kato, Y., Takebayashi, A. \& Shiga, A. (1999). Effects of supplemental chromium and isolation stress on tissue responsiveness and sensitivity to insulin in sheep. Small Ruminant Research 33, 239-246.

SAS (1985). SAS User's Guide: Statistics. SAS Inst., Inc., Cary, NC.

TAYLOR, K. A. (1996). A simple colorimetric assay for muranic acid and lactic acid. Applied Biochemistry and Biotechnology 56, 49-58.

TSERNG, K. \& KalHAN, S. C. (1983). Estimation of glucose carbon recycling and glucose turnover with [U- $\left.{ }^{13} \mathrm{C}\right]-$ glucose. American Journal of Physiology 245, E476-E482.

Yang, W. Z., Mowat, D. N., SubiYatno, A. \& Liptrap, R. M. (1996). Effects of chromium supplementation on early lactation performance of Holstein cows. Canadian Journal of Animal Science 76, 221-230. 